\title{
PROSEDUR SYARAT PENGAJUAN PATEN SEBAGAI HAK ATAS KEKAYAAN INTELEKTUAL DIINDONESIA
}

M.Fadel Zulkarnain

785567967

University Of Mitra Indonesia

Fadelzukarnain.student@umitra.ac.id

\begin{abstract}
Hak atas Kekayaan Intelektual (HaKI) penting untuk mengukuhkan penemuan para dosen. Salah satu perlindungan Hak atas Kekayaan Intelektual adalah mematenkan hasil penemuan. Di masyarakat umum mengartikan HaKI dan Paten dipahami sebagai istilah yang sama.Paten salah satu bagian Hak atas Kekayaan Intelektual atau HaKI yang berfungsi untuk melindungi karya intelektual dosen, mahasiswa dan masyarakat umum yang menghasilkan karya. Karya intelektual bermacam-macam, mulai yang bersifat teknologi (invensi), penelitian, seni dan masih banyak lagi. Salah satu contoh karya intelektual invensi yang dapat dipatenkan dapat berupa produk dan proses. Misalnya penemuan alat untuk mengukur kadar $\mathrm{pH}$ dalam air untuk mengetahui kadar normal untuk tanaman
\end{abstract}

Kata Kunci : Ketetapan UU No 31 Tahun 2000, Pengajuan Paten,Syarat pengajuan Paten 
industri lrelatif mudah memperoleh hak paten. Termasuk penemuan metode program komputer, presentasi mengenai informasi yang ditemukan lebih mudah memperoleh ijin paten. Meskipun demikian, ada pula karya intelektual yang ternyata tidak dapat dipatenkan. Berikut karya intelektual yang tidak dapat dipatenkan.

Karya/penemuan yang dapat di patenkan harus memenuhi syarat secara substantif. Secara substantif dibagi menjadi dua hal sebagai berikut.

\section{- Bersifat Baru}

Hasil karya intelektual belum pernah dipublikasikan terlebih dahulu. Baik di publikasikan di media apapun. Adapun langkah yang harus segera di urus agar memperoleh hak paten, dengan mengajukan permohonan. Setelah mengajukan permohonan, akan memperoleh tanggal penerimaan. Jika karya intelektual dipublikasikan sebelum memperoleh tanggal penerimaan, maka permohonan bisa gagal.

\section{- Bersifat Inventif}

Prinsip memperoleh paten HaKI bersifat inventif, atau kemampuan untuk menciptakan, merancang sesuatu yang sebelumnya belum pernah ada. Paten hanya diberikan pada karya intelektual hanya diberikan pada penemu yang memiliki person skilled in the art.

- Bersifat Aplikatif

Maksud aplikatif hasil penelitian yang ditemukan dapat dilakukan secara berulang-ulang. Dapat juga diartikan memiliki tingkat kemanfaatan bagi masyarakat. Semakin hasil penemuannya digunakan masyarakat luas, mengindikasikan bahwa penemuannya berhasil sebagai solusi atas permasalahan yang muncul. Karya intelektual memiliki syarat konsisten, tidak mudah berubah-ubah.

Karya intelektual yang bersifat kreasi estetika seperti hak cipta dan desain

- Karya intelektual tidak menentang peraturan Hak atas Kekayaan Intelektual. Diantarannya, tidak mengumumkan karya sebelum mengajukan surat permohonan. Hasil karya intelektual tidak bertentangan dengan peraturan undang-undangan yang berlaku. Hasil karya juga tidak menentang moralitas agama, mengandung RAS dan menganggu ketertiban umum.

- Karya intelektual tidak dalam praktik coba-coba. Karya intelektual bukan termasuk metode-metode dan teori. Misalnya metode pemeriksaan, pengobatan, perawatan, pembedahan dan pengobatan. Termasuk teori dan rumus matematika. Sehebat apapun rumus menyelesaikan permasalahan, tetap tidak dapat dipatenkan.

\section{Catatan Memperoleh Hak Paten}

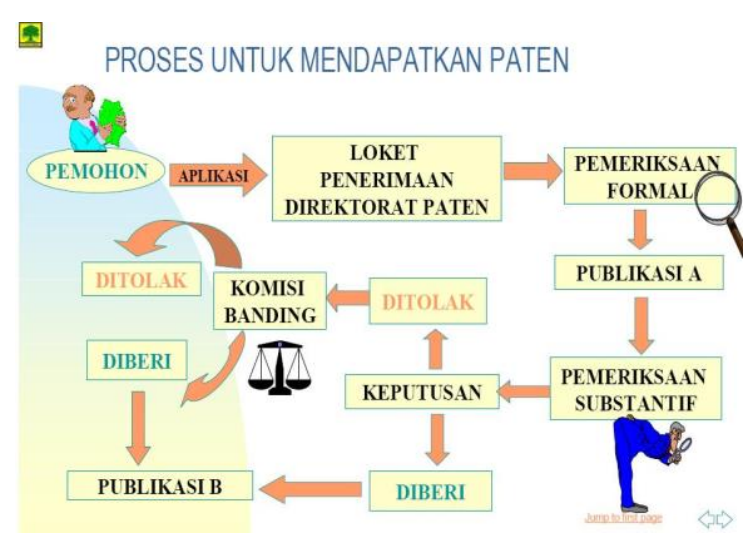

Pemilik karya intelektual disebut dengan istilah inventor. Inventor bisa dilakukan secara individu maupun kelompok. Inventor lebih mudah mendapatkan hak paten atas hasil penemuan karya intelektual mereka. Sedangkan untuk diluar inventor terlebih dahulu 


\section{B. LITERATURE REVIEW}

Hak paten diberikan pada inventor pertama kali yang mengajukan permohonan paten. Waktu pengajuan permohonan bersifat krusial dan bersifat time-sensitive. Dengan kata lain, apabila ada dua inventor yang memiliki karya intelektual yang sama persis, maka yang diakui adalah inventor yang lebih dulu mengajukan permohonan. Alaxander Graham Bell dinobatkan sebagai penemu telepon karena selangkah lebih cepat mendaftarkan hak patennya daripada kompetitornya pada waktu itu.

Hak paten dalam HaKI bagi mereka yang sudah tahu, berbondong-bondong mengajukan permohonan. Biaya permohonan hak paten sebesar Rp. 750.000,00. Sekalipun mereka sebenarnya masih ragu untuk memastikannya. Menariknya, ada sebagian yang tidak mempedulikan biaya pendaftaran paten untuk karya intelektual yang tidak komersial. Mereka tetap tidak merasa rugi, karena memperoleh hak paten lebih penting dari sekedar keuntungan secara ekonomi. Mengingat, hak paten tidak dapat dipatenkan lagi apabila sudah dipublikasikan.

\section{Prosedur Mengajukan Permohonan Hak Paten HaKI}

Syarat mengajukan permohonan hak paten HaKI karya intelektual benarbenar terbarukan. Belum ada yang pernah mengajukan sebelumnya. Adapun cara pengecekan apakah karya kita terbarukan atau tidak. kita dapat melakukan pengecekan dokumen paten di database DJHKI dan kantor paten di luar negeri. Misalnya, pengecekan terhadap jurnal ilmiah dan sejenisnya.

Jika karya kita belum bersifat terbarukan, proses selanjutnya adalah membuat proposal pengajuan paten. 
dapat mengajukan secara tertulis kepada DJHKI.

Proposal pengajuan paten meliputi judul invensi, latar belakang invensi, deskripsi singkat karya intelektual yang ditemukan dan gambar teknik. Gambar teknik yang disertai dengan uraian singkat. Kemudian dilengkapi dengan abstrak dan klaim. Rangkaian inilah yang kemudian disebut dengan penyusunan spesifikasi paten.

Spesifikasi paten sebagai syarat minimum yang harus disertakan. Adapun tiga syarat yang harus dipenuhi untuk memperoleh filing date, diantarannya memenuhi Spesifikasi paten, formulir permohonan dan biaya pendaftaran. Adapun persyaratan lain sebagai formalitas, dimana syarat ini dapat dilengkapi selama tiga bulan setelah menerima tanggal penerimaan. Berikut syarat permohonan yang perlu dipersiapkan.

- Surat pernyataan hak

- Surat perngalihan hak

- Surat kuasa

- Fotocopi KTP/identigas pemohon

- Fotokopi Akta pendirian badan hukum yang dilegaliris

- Fotokopi NPWP badan hukum

- Fotokopi KTP atas nama pemohon badan hukum untuk ditandatangai surat pernyataan dan surat kuasa.

Apabila syarat poin di atas sudah lengkap, inventor tinggal menunggu hasil dari DJHKI. Pengumuman akan dipublikasikan secara umum setelah 18 bulan dari hasil pengajuan. Pemohon paten selama menunggu pengumuman dimuat di berita resmi paten dan media resmi. Tujuannya untuk mengetahui hak kekayaan intelektual yang dipatenkan. Apabila masyarakat atau inventor luar merasa keberatan karena dianggap tidak memenuhi syarat untuk dipatenkan,
Khusus inventor yang ditolak, diperbolehkan mengajukan banding ke Komisi Banding Paten. Nantinya, akan berlanjut ke Pengadilan Niaga dan kasasi Mahkamah Agung. Apabila inventor pengajuan hak paten tetap ditolak, maka hasil hak kekayaan intelektual akan menjadi public domain. Sedangkan untuk yang memperoleh hak paten, akan meperoleh sertifikat hak paten dari DJHKI.

Itulah ulasan tentang Hak Paten Hak atas Kekayaan Intelektual (HaKI). Mengingat syarat dan prosederu pengajuan paten HaKI cukup panjang, ulasan ini bermanfaat. Selamat berkarya melahirkan karya intelektual.

\section{RESULT}

\section{Hak-hak yang Tercakup Dalam Hak Cipta}

\section{Hak eksklusif}

Beberapa hak eksklusif yang umumnya diberikan kepada pemegang hak cipta adalah hak untuk:

- Membuat salinan atau reproduksi ciptaan dan menjual hasil salinan tersebut (termasuk, pada umumnya, salinan elektronik),

- Menciptakan karya turunan atau derivatif atas ciptaan (mengadaptasi ciptaan),

- Menampilkan atau memamerkan ciptaan di depan umum,

- Menjual atau mengalihkan hak eksklusif tersebut kepada orang atau pihak lain. ada lembaga konsultan HaKI. Semoga

- Mengimpor dan mengekspor ciptaan, 


\section{CONCLUSION}

Yang dimaksud dengan "hak eksklusif" dalam hal ini adalah bahwa hanya pemegang hak ciptalah yang bebas melaksanakan hak cipta tersebut, sementara orang atau pihak lain dilarang melaksanakan hak cipta tersebut tanpa persetujuan pemegang hak cipta. Konsep tersebut juga berlaku di Indonesia. Di Indonesia, hak eksklusif pemegang hak cipta termasuk "kegiatan menerjemahkan, mengadaptasi, mengaransemen, mengalih wujudkan, menjual, menyewakan, meminjamkan, mengimpor, memamerkan, mempertunjukkan kepada publik, menyiarkan, merekam, dan mengkomunikasikan ciptaan kepada publik melalui sarana apapun".Selain itu, dalam hukum yang berlaku di Indonesia diatur pula "hak terkait", yang berkaitan dengan hak cipta dan juga merupakan hak eksklusif, yang dimiliki oleh pelakukarya seni (yaitu pemusik, aktor, penari, dan sebagainya), produser rekaman suara, dan lembaga penyiaran untuk mengatur pemanfaatan hasil dokumentasi kegiatan seni yang dilakukan, direkam, atau disiarkan oleh mereka masing-masing (UU 19/2002 pasal 1 butir 9-12 dan bab VII).

Sebagai contoh, seorang penyanyi berhak melarang pihak lain memperbanyak rekaman suara nyanyiannya. Hak-hak eksklusif yang tercakup dalam hak cipta tersebut dapat dialihkan,misalnya dengan pewarisan atau perjanjian tertulis (UU 19/2002 pasal 3 dan 4). Pemilik hak cipta dapat pula mengizinkan pihak lain melakukan hak eksklusifnya tersebut denganlisensi, dengan persyaratan tertentu (UU 19/2002 bab V).
Hak Atas Kekayaan Intelektual (HAKI) adalah hak kekayaan intelektual yang dilindunginoleh undang-undang. Setiap orang wajib menghormati hak kekayaan intelektual oranglain.Hak kekayaan intelektual tidak boleh digunakan oleh oranglain tanpa izin pemiliknya, kecualiapabila ditentukan oleh undang-undang. Perlindungan hukum berlaku bagi hak kekayaanintelektual yang sudah terdaftar dan dibuktikan dengan sertifikat pendaftaran.Munculnya pembajakan software di Indonesia tidak lepas dari kondisi sosial ekonomi yangada dimasyarakat kita, dimana setelah adanya krisis ekonomi yang melanda Negara kita,kondisi ekonomi dan sosial masyarakat kita menjadi kian merosot dan tidak teratur. Kondisiinilah yang menjadi landasan kuat dari para pembajak untuk membuat produk bajakan yangmurah. Berkembangnya pembajakan ini tidak lepas dari peran masyarakat itu sendiri, dimanamasyarakat sebagai konsumen tidak hanya merasa tidak bersalah dengan membeli produkhasil bajakan, tetapi sering kali merasa diuntungkan dengan sangat murahnya harga softwarehasil bajakan.Oleh karena itu, penegakkan hukum harus menjadi tumpuan utama dalam melakukan pemberantasan

pembajakan terhadap hak atas kekayaan intelektual. Penegakan hukum inimerupakan upaya yang dilakukan untuk menjadi hukum, baik dalam arti hukum yang sempitmaupun dalam arti materiil yang luas, sebagai pedoman prilaku dalam setiap perbuatanhukum, baik oleh para subyek hukum yang bersangkutan maupun oleh para aparatur penegakhukum yang resmi diberi tugas dan kewenangan oleh Undang - Undang untuk menjamin berfungsinya norma - norma hukum yang berlaku dalam 


\begin{tabular}{lrr} 
kehidupan & \multicolumn{2}{c}{ bermasyarakat } \\
danbernegara.Prinsip-prinsip & yang \\
terdapat di dalam & Hak Kekayaan \\
Intelektual adalah & sebagai berikut \\
:Prinsip & EkonomiPrinsip \\
KeadilanPrinsip & SosialPrinsip \\
KebudayaanKlasifikasi Hak Kekayaan \\
Intelektual dibagi menjadi 2 kelompok, \\
yaitu : \\
1. Hak Cipta \\
2. Hak Kekayaan Industri
\end{tabular}

E. ACKNOWLEDGEMENT

University Of Indonesia

University Of Mitra Indonesia

Telkom University

University Of Mellbourne

Saitama University 


\section{F. REFERENCES}

[1] A. S. Putra, H. Sukri, and K. Zuhri,"'SistemMonitoring Realtime Jaringan Irigasi Desa (JIDES)DenganKonsep Jaringan Sensor Nirkabel," IJEIS (Indonesian J. Electron. Instrum. Syst., vol. 8, no. 2, pp. 221-232.

[2] D. P. Sari, O. M. Febriani, and A. S. Putra, "Perancangan Sistem Informasi SDM Berprestasi pada SD Global Surya," in Prosiding Seminar Nasional Darmajaya, 2018, vol. 1, no. 1, pp. 289-294.

[3] A. S. Putra, "Paperplain: Execution Fundamental Create Application With Borland Delphi 7.0 University Of Mitra Indonesia," 2018.

[4] A. S. Putra, D. R. Aryanti, and I. Hartati, "Metode SAW (Simple Additive Weighting) sebagai Sistem Pendukung Keputusan Guru Berprestasi (Studi Kasus: SMK Global Surya)," in Prosiding Seminar Nasional Darmajaya, 2018, vol. 1, no. 1, pp. 85-97.

[5] A. S. Putra and O. M. Febriani, "KnowledgeManagement Online Application in PDAM LampungProvince,"in Prosiding International conference on Information Technology and Business (ICITB), 2018, pp. 181-187.

[6] A. S. Putra, O. M. Febriani, and B. Bachry,"Implementasi Genetic Fuzzy System Untuk Mengidentifikasi Hasil Curian Kendaraan Bermotor Di Polda Lampung," SIMADA (Jurnal
Sist. Inf. dan Manaj. Basis Data), vol. 1, no. 1, pp. 21-30, 2018.

[7] A. S. Putra, "2018 Artikel Struktur Data, Audit Dan Jaringan Komputer," 2018. O. M. Febriani and A. S. Putra, "Sistem Informasi Monitoring Inventori Barang Pada Balai Riset Standardisasi Industri Bandar Lampung," J. Inform., vol. 13, no. 1, pp. 90-98, 2014. 